\title{
DAMPAK PENGGUNAAN GADGET TERHADAP PERKEMBANGAN PERILAKU ANAK REMAJA MASA KINI
}

\author{
Jenny Gabriela ${ }^{1 *}$, Belinda Mau² \\ 1,2Sekolah Tinggi Teologi Excelsius Surabaya \\ *Email: Jennygabriela327@gmail.com
}

\section{THE IMPACT OF GADGET USAGE ON THE DEVELOPMENT OF BEHAVIOR OF TODAY'S ADOLESCENTS}

\begin{abstract}
The use of gadgets always has an impact on the development of children's behavior, because gagjed has various interesting, varied, and flexible features and applications so that it can add attractiveness to everyone, especially among children, nowadays gadjed can have a negative impact on the development of children's behavior The development of children's behavior seeks to psychology where due to playing Gadgej children become irritable, disobedient, lazy to learn, and can mimic behavior in gegjed. Children have now become active consumers where many electronic products and gadgets make children their market. "Moreover, not children, parents are also very helpful gadgets to the point of being called gadget freak Gadget. It is hoped that it will provide benefits for its users, where users must be able to operate gadgets properly, see gadget functions, and see the benefits of gadget applications.
\end{abstract}

Keywords: The impact of using Gadjed, the development of children's behavior

\begin{abstract}
Abstrak : Penggunaan gadget selalu berdampak pada perkembangan tinggkah laku anak, karena gagjed memiliki berbagai fitur dan aplikasi yang menarik, bervariasi, dan feksibel sehingga dapat menambah daya Tarik bagi setiap orang, khususnya dikalangan anak-anak sekarang ini gadjed dapat memberikan dampak negatif bagi perkembangan tingkah laku anak. Perkembangan tingkah laku anak berupaya pada psikologi dimana akibat bermain gadgej anak menjadi mudah marah, suka membangkang, malas belajar, dan bisa menirukan tingkah laku didalam gegjed. Anak-anak kini telah menjadi konsumen aktif dimana banyak produk-produk elktronik dan Gadget yang menjadikan anak-anak sebagai pasar mereka. " Apalagi jaman sekarang anak-anak, orang tua pun ada yang sangat menyukai gadget sampai disebut gadget freak.Gadget diharapkan memberikan manfaat bagi para penggunanya, dimana para penggunanya harus mampu mengoperasikan gadget dengan baik, mengetahui fungsi gadget, dan mengetahui manfaat dari aplikasi gadget.
\end{abstract}

Kata Kunci: Dampak Penggunaan Gadjed, Perkembangan Perilaku Anak

\section{PENDAHULUAN}

Kehidupan manusia di era digital saat ini mengalami perkembangan tekonologi yang luar biasa. ${ }^{1}$ Perkembangan teknologi digital juga telah memasuki hubungan keluarga. Hal itu menjadikan seluruh unsur keluarga, baik orangtua maupu anak-anak

${ }^{1}$ Aslan, "Peran Pola Asuh Orangtua di Era Digital," Jurnal Studia Insania 7, no. 1 (2019): 2034. menjadi penggunaan media digital salah satunya adalah media gadget. ${ }^{2}$ Indonesia merupakan penggunaan internet terbesar di Asia Tenggara yang memiliki pengguna yang paling aktif dimedia sosial. Menurut data Global Wax menemukan bahwa

\footnotetext{
${ }^{2}$ Dyna Herlina S. dkk., Digital Parenting: Mendidik Anak di Era Digital (Yogyakarta: Samudra Biru, 2018), 7-10.
} 
kecanduan gadget dapat memepengaruhi perkembangan otak anak karena hormone dopamiene yang berlebihan mengganggu kematangan fungsi prefrontal korteks.

Dampak gadget di era globalisasi membawa dampak positif dan negative. Adanya kemudahan dalam mencari informasih, pengetahuan, bisa mendapatkan atau saling berkomunikasi jarak jauh merupakan dampak salah satu dampak positif. Adanya perilaku anak yang kurang bersosialisasi, tidak mengerti sopan satun sebagi dampak tidak pernah bersosialisasi merupakan dapak negative yang banyak dikeluhkan perkembangan sosial pada anak. ${ }^{3}$ Menurut Dr. Jenny Radesky dari Baston University of Medicine mengatakan bahwa penggunaan gadget saat ini semakin intensif akan memberikan dampak pada pekembangan perilaku anak. Hal ini susuai dengan hasil penelitian yang menunjukkan bahwa terdapat hubungan antara intensitas penggunaan gadget terhadap interaksi sosial anak. Anak yang dianggap sudah kebiasaan bermain gadget jika dalam waktu sehari bermain dengan gadget lebih dari dua jam, dan jika gadget diambil anak akan marah bahkan tantrum. Seorang pecandu gadget hanya akan tertuju kepada dunia maya. hal ini akan menyatakan sebuah respon yang terjadi melalui interaksi dalam lingkungannya, yang kemudian akan menimbulkan perubahan tingkah laku. ${ }^{4}$ Sebagian besar anak ataupun remaja

${ }^{3}$ Sylvie Puspita, Fenomena Kecanduan Gadget pada anak Usia Dini (Surabaya: Cipta Media Nusantara, 2020), 2.

${ }^{4}$ Misdayanti, Penguatan dan Inovasi Pelayanan Kesehatan dalam Eera Revalusi Industry 4.0 (Kendari: UHO Edupress 2019), 283.

${ }^{5}$ Azimah Subagijo, Diet dan Detoks Gadget (Jakarta: PT Mizan Publika, 2020), 1.

${ }^{6}$ A.R. Fathoni, "Pengaruh Gadget terhadap Perkembangan Anak Usia Dini," Http://Www.Artikelcakep.Top/2017/10/Pengaruhg meningkat komsumsi penggunaan Gadget dari waktu ke waktu. Salah satu sebabnya kurangnya pengawasan dari orang tua atau bahkan meniru perilaku orang tua dan orang-orang dewasa disekitarnya. ${ }^{5}$ Gadget merupakan teknologi yang sangat popular sekarng ini, orang dewasa maupun anakanak mengunakan Gadget. Dimana banyakbanyak produk-produk gadget yang menjadikan anak sebagai target pasar mereka dan anak-anak kini telah menjadi konsumen aktif penggunaan gadget. $^{6}$ Gadget adalah sebuah istilah dalam Bahasa inggris yang mengartikan sebuah alat elektronik kecil dengan berbagai macam fungsi khusus.

Gadget (Bahasa Indonesia) adalah suatu istilah yang berasal dari Bahasa inggris untuk merunjuk pada suatu peranti atau instrument yang memiliki tujuan dan fungsi praktis spesifik yang berguna yang umumnya diberikan terhadap sesuatu yang baru. $^{7}$ Gadget dalam pengertian umum dianggap sebagai suatu perangkat elektronik yang memiliki fungsi khusus pada prangkatnya. Anak-anak kini telah menjadi konsumen aktif dimana banyak produk-produk elktronik dan Gadget yang menjadikan anak-anak sebagai pasar mereka. Apalagi jangan anak-anak, orang tua pun ada yang sangat menyukai gadget sampai disebut gadget freak. $^{8}$ Zaman sekarang, gadget tidak hanya dipakai oleh para pembisnis saja, banyak para remaja

adget-Terhadap-

PerkembangananakArtikelcakep.Html.

${ }^{7}$ A.P. Chusna, "Pengaruh Media Gadget pada Perkembangan Karakter Anak," Jurnal Dinamika Penelitian 17, no. 2 (2017): 315-330. Https://Doi.Org/10.21274/Dinamika/2017.17.2.315 $-330$

${ }^{8}$ Wahyu Novitasari, Dampak Penggunaan Gadget terhadap Interaksi Sosial Anak. Disertasi (Surabaya: Universitas Negeri Surabaya, 2016), 22. 
kan anak-anak pun telah banyak menggunakan gadget. Pada masa ini seluruh aspek perkembangan kecerdasan intelektual, emosi dan spiritual mengalami perkembangan yang luar biasa sehingga yang akan mempengaruhi dan menentukan perkembangan selanjutnya sampai dewasa. ${ }^{9}$ Hasil penelitian juga diperoleh bahwa proses sosialisasi mempunyai kedudukan strategis bagi anak untuk dapat membina hubungan dalam berbagai lingkungan. Kegagalan dalam proses sosialisasi menyebabkan seseorang menjadi pemalu, kurang percaya diri, menyendiri, keras kepala.

Perkembangan teknologi informasi dan komunikasi sudah sedemikian cepat sehingga tanpa disadari sudah mempengaruhi setiap aspek kehidupan manusia. Dewasa ini produk teknologi sudah menjadi kebutuhan sehari-hari dalam menjalankan aktivitas kehidupan. Penggunaan internet sudah bukan menjadi hal yang aneh ataupun baru lagi, khususnya di kota-kota besar bahkan sudah menjadi media paling penting dalam media pemasaran. ${ }^{10}$ Bahkan media seperti televisi, gadget, internet, smartphone, laptop bukan hanya beredar di perkotaan namun telah menjangkau hingga pelosok-pelosok desa. Belajar adalah suatu proses usaha yang dilakukan seseorang untuk memperoleh perubahan tingkah laku yang baru secara keseluruhan, sebagai hasil pengalamannya sendiri dalam interaksi dengan lingkungannya. ${ }^{11}$

${ }^{9}$ Yudrik Yahya, Psikologi Perkembangan (Jakarta: PT Kharisma Putra Utama, 2000), 23.

${ }^{10}$ Dewi Irmawati, "Pemanfaatan ECommerce dalam Dunia Bisnis", Jurnal Ilmiah Orasi Bisnis, (November 2011): 95-112

${ }^{11}$ Hamdani, Strategi Belajar Mengajar (Bandung: Pustaka Setia, 2011), 20.

${ }^{12} \mathrm{~S}$. Ameliola \& D.N. Hanggara, "Perkembangan Dunia Informasi dan Teknologi

\section{METODE}

Tulisan ini menggunakan metode kualitatif deskriptif. Teknik pengumpulan data yang digunakan ialah dengan pendekatan studi pustaka, yaitu pengumpulan dokumen berupa sumbersumber buku, jurnal, dan media lainnya yang mendukung pembahasan dalam tulisan ini.

\section{PEMBAHASAN}

\section{Penggunaan Gedget}

Perkembagan teknologi dan informasi mengalami kemajuan yang sangat pesat, ditandai dengan kemajuan pada bidang informasi dan teknologi. Bangsa Indonesia merupakan salah satu bangsa yang ikut terlibat dalam kemajuan media informasi dan teknologi. ${ }^{12}$

Pada era sekarang gadget dengan berbagai aplikasi dapat menyajikan berbagai media sosial, sehingga seringkali disalah gunakan oleh siswa. Penggunaan gadget yang berlebihan pada siswa terkadang sering menimbulkan masalah pada proses belajar. Penggunaan gadget berdampak merugikan pada keterampilan interpersonal anak jika terlalu sering digunakan. Pegaruh handphone terhadap prestasi belajar siswa yang lain adalah siswa lebih mengandalkan handphone dari pada harus belajar. ${ }^{13}$

$$
\text { Penggunaan gadget secara }
$$

berkelanjutan dan akan berdampak buruk bagi pola perilaku anak dalam kesehariannya, anak-anak yang cenderung

terhadap Anak dalam Era Globalisasi," Jurnal Konferensi Internasional https://icssis.wordpress.com/prosiding/prosidingicssis-2013/prosidingicssis-2013-jilid-2/.

${ }^{13}$ Nurmalasari, "Pengaruh Penggunaan Gadget terhadap Tingkat Prestasi That are Easy to Carry Anywhere for," Jurnal Ilmu Pengetahuan dan Teknologi Komputer 3, no. 2 (2018 ): 111-118. 
terus-menerus menggunakan gadget akan sangat tergantung dan menjadi kegiatan yang harus dan rutin dilakukan oleh anak dalam aktifitas sehari-hari. Bisa dikatakan juga bahwa Gadget merupakan sebuah media modern yang dapat diartikan sebagai sebuah benda/alat yang sangat penting, yang dapat dipergunakan untuk semua bidang kehidupan, sebagaimana peralatan elektronik yang lain, gadget menjadikan pedang bermata dua, apabila dimanfaatkan dengan baik, dia akan memberikan manfaat bagi orang dewasa maupun anak-anak. ${ }^{14}$

Menurut Osa Kurniawan, "gadget adalah sebuah perangkat atau perkakas mekanis yang mini atau sebuah alat yang menarik karena relatif baru karena akan banyak memberikan kesenangan baru bagi penggunanya walaupun mungkin tidak praktis dalam penggunaannya". Sedangkan menurut Muhammad Risal (Wikipedia.com, 2011) dalam Rohmah (2017), "gadget adalah sebuah istilah yang berasal dari bahasa Inggris, yang artinya perangkat elektronik kecil yang mempunyai fungsi khusus"15. Bisa dikatakan juga bahwa Gadget merupakan sebuah media modern yang dapat diartikan sebagai sebuah benda/alat yang sangat penting, yang dapat dipergunakan untuk semua bidang kehidupan, sebagaimana peralatan elektronik yang lain, gadget menjadikan pedang bermata dua, apabila dimanfaatkan dengan baik, dia akan memberikan manfaat bagi orang dewasa

\footnotetext{
${ }^{14}$ Rafid Rachmatullah, "Peranan Orang Tua dalam Mengatasi Dampak Negatif Penggunaan Gadget pada Anak di Desa Cikatomas Kecamatan Cilograng Kabupaten Lebak Provinsi Banten," FKIP Unpas, 2017.

${ }^{15}$ C.O. Rohmah, Pengaruh Penggunaan Gadget dan Lingkungan Belajar terhadap Minat Belajar Siswa Kelas XI Kompetensi Keahlian Administrasi Perkantoran SMK Muhammadiyah 2 (Yogyakarta: Fakultas Ekonomi UNY, 2017), 10.
}

maupun anak-anak. ${ }^{16}$ Wijanarko (2016:3) menyebutkan bahwa gadget baik laptop, ipad, tablet atau smartphone adalah alat teknologi yang berisi aneka aplikasi dan informasi mengenai semua hal yang ada didunia ini. ${ }^{17}$

Gadget mempunyai fungsi dan manfaat yang relatif sesuai dengan penggunaanya seperti menurut Puji Asmaul Chusna bahwa fungsi dan manfaat gadget secara umum sebagai berikut: ${ }^{18}$ 1) Komunikasi Pengetahauan manusia semakin luas dan maju. Jika zaman dahulu manusia berkomunikasi melalui batin, kemudian berkembang melalui tulisan yang dikirimkan melalui pos. Sekarang zaman era globalisasi manusia dapat berkomunikasi dengan mudah, cepat, praktis dan lebih efisien dengan menggunakan handphone. 2) Sosial Gadget memiliki banyak fitur dan aplikasi yang tepat untuk kita dapat berbagi berita, kabar, dan cerita. Sehingga dengan pemanfaatan tersebut dapat menambah teman dan menjalin hubungan kerabat yang jauh tanpa harus menggunakan waktu yang relatif lama untuk berbagi. 3) Pendidikan Seiring berkembangnya zaman, sekarang belajar tidak hanya terfokus dengan buku. Namun melalui gadget seseorang dapat mengakses berbagai ilmu pengetahuan yang seseorang perlukan. Tentang pendidikan, politik, ilmu pengetahuan umum, agama, tanpa harus repot pergi ke perpustakaan yang mungkin jauh untuk dijangkau. Dengan gadget,

\footnotetext{
${ }^{16}$ Rafid Rachmatullah, Peranan Orang Tua dalam Mengatasi Dampak Negatif Penggunaan Gadget pada Anak di Desa Cikatomas Kecamatan Cilograng Kabupaten Lebak Provinsi Banten, 11.

${ }^{17}$ Jarot Wijanarko \& Ester Setiawati, Ayah Baik-Ibu Baik Parenting Era Digital (Jakarta: Keluarga Indonesia Bahagia, 2016), 654.

${ }^{18}$ Asmaul Chusna, "Pengaruh Media Gadget pada Perkembangan Karakter Anak". Jurnal Dinamika Penelitian (2017), 315-330.
} 
anak-anak usia pra sekolah kebawah bisa belajar memahami materi-materi belajar seperti pengenalan alphabet, huruf hijaiyah, angka, mengenal hewan, tumbuhan, bendabenda di sekitar dan belajar menyanyi dengan melihat video dari youtube, bahkan orang tua juga bisa memberikan latihan kepada anak dengan memanfaatkan game yang bisa melatih ingatan dan keterampilan anak.

Belajar menggunakan Gadget Dalam dunia pendidikan, memberikan pelajaran dan pendidikan kepada anak usia perkembangan harus menggunakan cara yang aktif dan kreatif untuk memberi stimulasi terhadap perasaan senang anak sehingga pendidikan yang diberikan dapat mereka terima, karena jika anak merasa tidak senang, maka anak Dampak positif penggunaan gadget antara lain, yang pertama adalah gadget akan membantu perkembangan fungsi adaptif seorang anak artinya kemampuan seseorang untuk bisa menyesuaikan diri dengan keadaan lingkungan sekitar dan perkembangan zaman. Jika perkembangan zaman sekarang muncul gadget, maka anak pun harus tahu cara menggunakannya karena salah satu fungsi adaptif manusia zaman sekarang adalah harus mampu mengikuti perkembangan teknologi. Sebaliknya, anak yang tidak bisa mengikuti perkembangan teknologi bisa dikatakan fungsi adaptifnya tidak berkembang secara normal. Nilai positif lain adalah gadget memberi kesempatan anak untuk leluasa mencari informasi. Apalagi anak-anak sekolah sekarang dituntut untuk mengerjakan tugas melalui internet. ${ }^{19}$

\footnotetext{
${ }^{19}$ Mohammad Nazir, Metode Penelitian (Jakarta: Penerbit Ghalia Indonesia,2003), 15.

${ }^{20}$ Atik Dwi Susanti, Pengaruh Pemanfaatan Gadget dalam Aktivitas Belajar untuk
}

Dalam hal belajar, penggunaan gadget memiliki dampak positif antara lain: 1) Anak memiliki pengetahuan yang lebih luas karena dalam gadget tidak ada batasan dalam mencari informasi mengenai apapun dan dari manapun, anak bisa bebas memilih belajar apa saja seperti mata pelajaran, belajar menanam bunga, belajar cara menggambar, melukis, belajar membuat sesuatu dari barang bekas, dan banyak sekali pembelajaran yang bisa ditemukan di dalam gadget. 2) Menambah semangat belajar, anak akan memiliki semangat karena mereka bisa belajar dengan melihat gambar hidup, warna warni, karakter kartun yang semuanya itu mereka sukai dan membuat perasaan mereka senang, bukan sekedar belajar dengan buku dan pensil yang terkadang memberikan efek bosan untuk anak-anak dalam masa perkembangan. 3) Lebih mudah memahami pelajaran, hal ini dikarenakan belajar menggunakan gadget akan bisa menjumpai contoh konkrit, bukan hanya materi pelajaran, contohnya seperti pada videovideo pembelajaran tentang perilaku sopan santun, saling menghargai, saling menolong dan memaafkan.

Gadget diharapkan memberikan manfaat bagi para penggunanya, di mana para penggunanya harus mampu mengoperasikan gadget dengan baik, mengetahui fungsi gadget, dan mengetahui manfaat dari aplikasi gadget. $^{20}$ Gadget merupakan alat elektronik yang digunakan sebagai media informasi, media belajar, dan sebagai hiburan. Hampir semua kalangan memilikibarang kecil canggih tersebut. Gadget memiliki banyak fungsi bagi penggunanya sehingga dinilai lebih

Meningkatkan Hasil Belajar Ppkn Siswa di Kelas Xi Iis Sma Negeri 1 Seputih Mataram (Lampung: FKIP Universitas Lampung Bandar Lampung, 2018), 27. 
memudahkan untuk kebutuhan manusia. Namun dalam beberapa tahun terakhir ini, banyak permasalahan yang muncul akibat beredarnya sosial media, seperti meningkatnya kriminalitas, dan menurunnya moral pelajar.

Menurut Parsons, tindakan individu dipengaruhi oleh dua macam orientasi, yaitu orientasi motivasional yang bersifat pribadi dan orientasi nilai yang bersifat sosial. Hal ini mengantarkan pemahaman bahwa tindakan seseorang dipengaruhi oleh kehendak dirinya dan dikontrol oleh nilainilai yang berlaku di masyarakat. ${ }^{21}$

\section{Dampak Penggunaan Gadget}

Gadget juga dapat mempengaruhi perilaku sosial seseorang, bergantung pada cara orang tersebut menggunakan gadget tersebut. ${ }^{22}$ Ada beberapa dampak negatif karena berlebihan dalam penggunaan gadget pada perkemebangan anak yang membuat anak menjadi ketagihan atau kecanduan. ${ }^{23}$ Diantaranya adalah 1) Waktu terbuang sia-sia. Anak-anak akan sering lupa waktu ketika sedang asyik bermain gadget. Mereka membuang waktu untuk aktifitas yang tidak terlalu penting, padahal waktu tersebut dapat dimanfaatkan untuk aktifitas yang mendukung kematangan berbagai aspek perkembangan pada dirinya. 2) Perkembangan otak. Terlalu lama dalam penggunaan gadget dalam seluruh aktifitas sehari-hari akan menganggu perkembangan otak. Sehingga menimbulkan hambatan dalam kemampuan berbicara (tidak lancar komunikasi), serta menghambat kemampuan dalam

${ }^{21}$ Johnson K. dan K. Morrow, Communication in the Classroom Applications dan Methods for a Communicative Approach (Oxford: Oxford University Press, 2015), 5. mengeskpresikan pikirannya. 3) Banyaknya fitur atau aplikasi yang tidak sesuai dengan usia anak, miskin akan nilainorma, edukasi dan agama. 4) Menganggu kesehatan. Semakin sering menggunakan gadget akan menganggu kesehatan terutama pada mata. Selain itu akan mengurangi minat baca anak karena terbiasa pada objek bergambar dan bergerak. 5) Menghilangkan ketertarikan pada aktifitas bermain atau melakukan kegiatan lain. Ini yang akan membuat mereka lebih bersifat individualis atau menyendiri. Banyak dari mereka diakhir pekan digunakan untuk bermain gadget ketimbang bermain dengan teman bermain untuk sekedar bermain bola dilapangan. Penggunaan gadget yang berlebihan pada anak akan berdampak negatif karena dapat menurunkan daya konsentrasi dan meningkatkan ketergantungan anak untuk dapat mengerjakan berbagai hal yang semestinya dapat mereka lakukan sendiri. Dampak lainnya adalah semakin terbukanya akses internet dalam gadget yang menampilkan segala hal yang semestinya belum waktunya dilihat oleh anak-anak. Penggunaan gadget dapat mempengaruhi pola perilaku remaja dikarenakan adanya ketertarikan terhadap sesuatu seperti mengikuti gaya hidup artis yang dilihat dari media sosial sehingga kepribadian remaja pun mengikuti kepribadian artis yang ia sukai tersebut. Media sosial yang sejatinya sebagai alat berbagi informasi sering kali disalahgunakan sehingga pengguna media sosial dalam hal ini kalangan remaja sangat

22 Rita Kencana, Pengembangan Nilai Moral dan Agama Anak Usia Dini (Bandung: Edu Publiser, 2020), 145.

${ }^{23}$ Suwarsi, "Pengaruh Gadget terhadap Perkembangan Anak", Seminar Tanggal 25 September 2016. 
mudah terpengaruh dan mengikuti hal-hal baik itu negatif maupun positif di media sosial itu sendiri.

Dampak gadget pada anak paling dirasakan adalah penurunan dalam kemampuan bersosialiasi dengan orangorang disekitar. Ketika anak terlalu asyik bermain dengan gadget, anak dapat mengabaikan dan tidak peduli dengan lingkungan sekitar. Sehingga tidak memahami etika bersosialisasi dengan orang disekitarnya. Dengan mengakses situs jejaring di dunia maya secara berlebihan juga dapat membuat anak berpikir bahwa mencari teman bisa dilakukan melalui internet, dan melupakan teman-teman yang ada dilingkungan sekitar. Kemajuan teknologi berpotensi membuat anak cepat puas dengan pengetahuan yang diperolehnya sehingga menganggap apa yang didapatnya dari internet atau teknologi lain adalah pengetahuan yang terlengkap dan final.

Padahal banyak sekali yang harus digali pada proses pembelajaran secara tradisional yang bisa sangat efektif, bahkan adanya internet tidak akan bisa menggantikan proses pembelajaran dalam sebuah pencarian pengetahuan. Jika tidak dicermati, maka pada masa mendatang akan tercipta generasi yang akan cepat puas karena begitu mudahnya mencari informasi pada gadget. Dengan kata lain, anak-anak sekarang menganggap hidup itu seharusnya mudah yang pada akhirnya anak-anak akan memilih untuk menyederhanakan masalah dan menghindari kesulitan. Karena itu hasilnya anak makin hari makin lemah dalam hal kesabaran serta konsentrasi dan

${ }^{24}$ Aisyah Anggraeni dan Hendrizal Hendrizal, "Pengaruh Penggunaan Gadget terhadap Kehidupan Sosial Para Siswa SMA." Jurnal Pelita Bangsa Pelestari Pancasila 13, no. 1 (2018): 64-76. cepat menuntut orang untuk memberi yang diinginkannya dengan cepat. ${ }^{24}$

Adiksi gadget adalah perilaku keterikatan atau kecanduan terhadap smartphone yang memungkinkan menjadi masalah sosial, seperti halnya menarik diri dan kesulitan dalam performa aktivitas sehari-hari atau sebagai gangguan kontrol impuls terhadap diri seseorang. Menurut Chiu mengatakan bahwa adiksi smartphone adalah salah satu kecanduan yang memiliki resiko lebih ringan dari pada kecanduan alcohol ataupun kecanduan obat-obatan. Perilaku dapat dikatakan sebagai perilaku kecanduan apabila seseorang tidak dapat mengontrol keinginanya dan menyebabkan dampak negatif pada diri individu yang bersangkutan. $^{25}$

Dari beberapa dampak negatif penggunaan gadget diatas, maka dapat penulis simpulkan bahwa penggunaan gadget dapat berakibat negatif apabila seseorang atau anak-anak belum mampu mengolah waktu dan menyaringkonetn atau aplikasi apa saja yang termuat dapat sebuah gadget. Hal tersebut berakibat akan menimbulkan banyak dapat buruk dari penggunaan gadget diantaranya seperti: dapat menganggu kesehatan, menganggu perkembangan anak, dan seseorang akan lebih bersikap tertutup dengan lingkungan sekitar lebih lagi dapat mengganggu pengelolaan waktu belajar anak baik di sekolah maupun di rumah dan lingkungan masyarakat.

\section{Perkembangan Perilaku Anak}

Santrock mengatakan bahwa perkembangan adalah pola perubahan yang

\footnotetext{
${ }^{25}$ Yuwanto L., "Pengembangan Alat Ukur Blackberry Addict”. Jurnal Proceeding Pessat 5 (Oktober 2013).
} 
dimulai sejak pembuahan dan terus berlanjut disepanjang rentang kehidupan individu. Sebagian besar perkembangan melibatkan pertumbunhan, namun juga melibatkan (kemunduran) penuaan. Senada dengan Santrock, Hurlock mengemukakan bahwa perkembangan merupakan serangkaian perubahan progresif yang terjadi sebagai akibat dari proses kematangan dan pengalaman/belajar. ${ }^{26}$

Perkembngan

(development)

merupakan bertambahnya kemampuan dalam struktur dan fungsi tubuh yang lebih kompleks, terjadi dalam pola yang teratur sebagai hasil dari proses pematangan. Selsel tubuh, jaringan orang, dan sistem organ

Menurut teori psikososial maupun teori perkembangan kognitif menyatakan bahwa perilaku yang ada pada diri seorang berlandasan pada pertimbanganpertimbangan moral kognitif. Selanjutnya, masalah aturan, norma, nilai, etika, akhlak dan estetika adalah hal yang sering didengar dan selalu dihubungkan dengan konsep moral ketika seseorang akan menetapkan suatu keputusan perilakunya. ${ }^{27}$ Menurut psikolog, perilaku manusia berasal dari dorongan yang ada dalam diri manusia dan dorongan itu merupakan salah satu usaha untuk memenuhi kebutuhan yang ada dalam diri manusia. Dengan adanya dorongan tersebut, menimbulkan seseorang melakukan sebuah Tindakan atau perilaku khusus yang mengarah pada Tujuan. Kemampuan teknologi informasi dan multimedia dalam menyampaikan pesan dinilai sangat besar. Di tahun yang sudah termasuk modern ini, generasi muda Indonesia pun sudah akrab dengan yang

${ }^{26}$ Christiana Hari Soetjiningsi, Seri Psikologi Perkembangan Anak (Jakarta: Kencana, 2018), 2.

${ }^{27}$ Sjarkawi, Pembentukan Kepribadian Anak; Peran Moral intelektual, Emosional dan megalami proses diferensi, ditandai dengan kemapuan untuk bekerja sesuai fungsi masing-masing dan di dalamnya terdapat perkembangan emosi, intelektual dan tingkah laku sebagai hasil interaksi dengan lingkunganya. Perkembangan terjadi secara alami pada setiap individu karena di dalamnya terdapat komponen-komponen psikologi yang dapat menunjang perkembangan. Komponen psikologi dalam perkembangan individu meliputi: psikognitif, psiko-motorik dan psikoafektif. Perkembangan merupakan suatu proses yang Panjang, membutuhkan dukungan dan stimulasi untuk mencapai perkembangan yang optimal.

namanya teknologi dan segala peralatannya. Anak-anak dengan usia sekolah dasar pun sudah dibekali dengan pengenalan akan teknologi, akun-akun jaringan sosial, rata-rata banyak memiliki dan dikuasai oleh anak-anak sekolah, sebenarnya, teknologi digunakan untuk mempermudah keidupan manusia.

Pada setiap individu sesorang terdapat dua faktor utama yang sangat menentukan kehidupannya, yaitu fisik dan ruh. Pemahaman terhadap kedua faktor ini memberikan pengaruh yang sangat besar terhadap bagaimana seseorang berperilaku dalam realitas kehidupannya. Kedua faktor ini memiliki ruang dan dimensi yang berbeda. Jika yang pertama adalah sesuatu yang sangat mudah untuk diindra, tampak dalam bentuk perilaku, namun pada faktor yang kedua hanya dapat dirasakan dan menentukan terhadap baik buruknya suatu perilaku. ${ }^{28}$ Perilaku manusia adalah suatu fungsi dari interaksi antara individu dengan

Sosial sebagai Wujud Membangun Jati Diri (Jakarta: PT Bumi Aksara 2009), 26.

${ }^{28}$ Akh. Muwafik Saleh, Membangun Karakter dengan Hati Nurani (Jakarta: Erlangga, 2012), 103. 
lingkungannya. ${ }^{29}$ Karena pada hakikatnya individu memiliki keunikan masing-masing yang membedakan satu dengan yang lain. Inilah yang disebut manusia sebagai makhluk individu. Menurut Arthur S. Rober bahwa Perilaku atau tingkah laku adalah sebuah istilah yang sangat umum mencakup tindakan, aktivitas, respon, reaksi, gerakan, proses, operasi-operasi dsb. Singkatnya, respon apapun dari organisme yang bisa diukur. ${ }^{30}$

Perilaku yang terjadi pada seseorang didorong oleh motivasi. Penentu perilaku seseorang pada titik ini yaitu pada motivasi sebaga daya penggerak perilaku (the energizer) sekaligus menjadi. Motivasi juga dapat dikatakan sebagai suatu konstruk teoritis mengenai terjadinya perilaku. ${ }^{31}$ Dengan perkembangannya, gadget dengan jaringan internet yang sekarang mudah diakses membuat para pembuat situs berupaya menjual situs yang mereka buat. Salah satu cara yang dapat menarik perhatian biasanya tampilan seperti ini banyak terdapat pada aplikasi game yaitu dengan cara menampilkan kekejaman dan kesadisan. ${ }^{32}$ Pada sebuah penelitian yang menyatakan bahwa game yang dimainkan di komputer atau laptop yang menampilkan unsur kekerasan memiliki sifat menghancurkan yang lebih besar dibanding kekerasan yang ada di televisi ataupun kekerasan dalam kehidupan nyata sekali pun. Biasanya anak-anak dan remaja yang akan lebih mudah terpengaruh, sehingga bisa menimbulkan kurangnya sensitivitas

${ }^{29}$ Veithzal Rivai, Kepemimpinan dan Perilaku Organisasi (Jakarta: Rajawali Press, 2009), 230.

${ }^{30}$ Arthur S. Reber dan Emily S. Reber, Kamus Psikologi (Yogyakarta: Pustaka Pelajar, 2010), 217.

${ }^{31}$ Abdul Rahman Saleh, Psikologi: Suatu Pengantar dalam Perspektif Islam (Jakarta: Kencana, 2009), 182. terhadap sesama, memicu munculnya perilaku agresif, sadistis, bahkan bisa mendorong munculnya sikap kriminal yang ada pada game yang dimainkan sehingga dapat mengeser nilai sosial dari pada antar sesama manusia.

Menurut T. Ramli, pendidikan karakter memiliki esensi dan makna yang sama dengan pendidikan moral dan akhlak. ${ }^{33}$ Tujuannya adalah untuk membentuk pribadi anak supaya menjadi manusia yang baik, yaitu warga masyarakat dan Negara yang baik. Pendidikan karakter adalah upaya-upaya yang dirancang dan dilaksanakan secara sistematis untuk membantu peserta didik memahami nilainilai prilaku manusia yang berhubungan dengan Tuhan Yang Maha Esa, diri sendiri, sesama manusia, lingkungan, dan kebangsaan. Kemudian, nilai-nilai tersebut dapat terwujud dalam fikiran, sikap, perasaan, perkataan, dan perbuatan berdasarkan norma-norma agama, hukum, tata kerama, budaya, dan adat-istiadat. Dalam pendidikan karakter Muslich Masnur Lickona "menekankan pentingnya tiga komponen karakter yang baik (components of good character), yaitu moral knowing atau pengetahuan tentang moral, moral feeling atau perasaan tentang moral, dan moral action atau perbuatan moral". Hal ini diperlukan agar anak mampu memahami, merasakan dan mengerjakan sekaligus nilai-nilai kebijakan. Pendidikan karakter adalah pendidikan budi pekerti plus, yaitu yang

\footnotetext{
${ }^{32}$ Dahlia, Pengaruh Penggunaan Gadget terhadap Perilaku Sosial di SMA Darussalam Ciputat. Skripsi (Jakarta: Fakultas Ilmu Tarbiyah dan Keguruan 2009), 10-11.

${ }^{33}$ Jamal Ma'mur Asmani, Buku Panduan Internalisasi Pendidikan Karakter di Sekolah (Jogjakarta: Diva Presss, 2013), 32.
} 
melibatkan aspek pengetahuan (cognitive), perasaan (feeling), dan tindakan (action). Menurut Lickona Thomas, tanpa ketiga aspek ini, maka pendidikan karakter tidak akan efektif

Pendidikan karakter berfungsi, mengembangkan potensi dasar agar berhati baik, berpikiran baik, dan berperilaku baik, memperkuat dan membangun perilaku bangsa yang multicultural, meningkatkan peradaban bangsa yang kompetetif dalam pergaulan dunia. ${ }^{34}$ Penggunaan gadget dikarenakan tuntutan trend saat ini yang menuntuk mereka untuk aktif dalam dunia internet atau media sosial, oleh karena itu pada saat jam pelajaran, mereka juga sering menggunakan gadget unutk menutupi rasa bosan karena jam pelajaran yang panjang. Hal ini menyebabkan bahwa sebagaian materi yang dijelaskan oleh guru tidak lagi diserap dengan baik karena siswa tidak mampu berkonsentrasi lagi dengan pelajaran yang sedang berlangsung, yang dapat berakibat pada nilai akademik siswa, juga siswa menjadi jarang berkomunikasi dengan temannya karena lebih asik dengan gadget miliknya. Masih banyak orang tua yang belum melakukan pengawasan terhadap anaknya dalam penggunaan smartphone. Orang tua lebih memilih tidak mencampuri urusan anaknya, sikap orang tua seperti ini membuat anak merasa bebas untuk melakukan hal apapun yang mereka inginkan tanpa adanya kontrol dari orang tua. maka diharapkan agar terciptanya lingkungan yang kondusif bagi anak sehingga tidak melakukan perilaku penggunaan smartphone yang tinggi. Bentuk pengawasan bisa dilakukan dengan cara Orang tua dapat menanyakan perilaku anak kepada temannya, guru di sekolah, dan masyarakat sekitar untuk mengetahui apa saja yang dilakukan anak di luar rumah agar perilakunya dapat selalu terkontrol orang tua. ${ }^{35}$

\section{KESIMPULAN}

Di tahun yang sudah termasuk modern ini, generasi muda Indonesia pun sudah akrab dengan yang namanya teknologi dan segala peralatannya. Anakanak dengan usia sekolah dasar pun sudah dibekali dengan pengenalan akan teknologi, akun-akun jaringan sosial, ratarata banyak memiliki dan dikuasai oleh anak-anak sekolah, sebenarnya, teknologi digunakan untuk mempermudah keidupan manusia. Jika tidak dicermati, maka pada masa mendatang akan tercipta generasi yang akan cepat puas karena begitu mudahnya mencari informasi pada gadget. Jika perkembangan zaman sekarang muncul gadget, maka anak pun harus tahu cara menggunakannya karena salah satu fungsi adaptif manusia zaman sekarang adalah harus mampu mengikuti perkembangan teknologi. Gadget merupakan sebuah media modern yang dapat diartikan sebagai sebuah benda/alat yang sangat penting, yang dapat dipergunakan untuk semua bidang kehidupan, sebagaimana peralatan elektronik yang lain, gadget menjadikan pedang bermata dua, apabila dimanfaatkan dengan baik, dia akan memberikan manfaat bagi orang dewasa maupun anak-anak.
${ }^{34}$ Nanda Ayu Setiawati, "Pendidikan Karakter Sebagai Pilar Pembentukan Karakter Bangsa," Prosiding Seminar Nasional Tahunan Fakultas Ilmu Sosial Universitas Negeri Medan 1, no. 1 (2017): 349.
${ }^{35}$ Bisma Mukti Wibowo, Kementrian Kesehatan Republik Indonesia Politeknik Kesehatan Jakarta I (Jakarta: Ka. Unit TI, 2012), 2. 


\section{DAFTAR PUSTAKA}

A.P., Chusna. "Pengaruh Media Gadget pada Perkembangan Karakter Anak." Jurnal Dinamika Penelitian 17, 2 (2017 ): 315-330. Doi.Org/10.21274/Dinamika/2017. 17.2.315-330.

Abdul, Saleh Rahman. Psikologi: Suatu Pengantar dalam Perspektif Islam. Jakarta: Kencana, 2009.

Ameliola, S. \& Hanggara, D.N. Perkembangan Dunia Informasi dan Teknologi terhadap Anak dalam Era Globalisasi. Jurnal Konferensi Internasional tentang Studi Indonesia.

https://icssis.wordpress.com/prosidin g/prosiding-icssis-

2013/prosidingicssis-2013-jilid-2/.

Anggraeni, Aisyah, and Hendrizal Hendrizal. "Pengaruh Penggunaan Gadget terhadap Kehidupan Sosial Para Siswa SMA." Jurnal Pelita Bangsa Pelestari Pancasila 13, no. 1,2018.

Aslan, "Peran Pola Asuh Orangtua di Era Digital." Jurnal Studia Insania 7, no.1 (2019): 20-34.

Asmaul, Chusna. "Pengaruh Media Gadget pada Perkembangan Karakter Anak." Jurnal Dinamika Penelitian17, 2 (2017): 315-330.

Dahlia. Pengaruh Penggunaan Gadget terhadap Perilaku Sosial di SMA Darussalam Ciputat. Skripsi. Jakarta: Fakultas Ilmu Tarbiyah dan Keguruan, 2009.

Dewi, Irmawati. "Pemanfaatan ECommerce dalam Dunia Bisnis." Jurnal Ilmiah Orasi Bisnis VI (November 2011).

Dyna Herlina S., dkk. Digital Parenting: Mendidik Anak di Era Digital. Yogyakarta: Samudra Biru, 2018.
Fathoni A, R., "Pengaruh Gadget terhadap Perkembangan Anak Usia Dini." Http://Www.Artikelcakep.Top/2017/ 10/Pengaruhgadget-TerhadapPerkembangananakArtikelcakep.Ht $\mathrm{ml}$.

Hamdani. Strategi Belajar Mengajar. Bandung: Pustaka Setia, 2011.

Johnson, K. and K. Morrow. Communication in the Classroom Applications and Methods for a Communicative Approach. Oxford: Oxford University Press, 1981.

L., Yuwanto. "Pengembangan Alat Ukur Blackberry Addict." Jurnal Proceeding Pessat 05 (Oktober 2013).

Ma'mur, Asmani Jamal. Buku Panduan Internalisasi Pendidikan Karakter di Sekolah. Jogjakarta: Diva Presss, 2013.

Misdayanti. Penguatan dan Inovasi Pelayanan Kesehatan dalam Era Revalusi Industry 4.0. Kendari: UHO Edupress, 2019.

Nazir, Mohammad. Metode Penelitian. Jakarta: Penerbit Ghalia Indonesia, 2003.

Nurmalasari. "Pengaruh Penggunaan Gadget terhadap Tingkat Prestasi That are Easy to Carry Anywhere for. " Jurnal Ilmu Pengetahuan dan Teknologi Komputer 3, no. 2 (2018): 111-118.

Rachmatullah, Rafid. "Peranan Orang Tua dalam Mengatasi Dampak Negatif Penggunaan Gadget pada Anak di Desa Cikatomas Kecamatan Cilograng Kabupaten Lebak Provinsi Banten." Bogor: FKIP Unpas, 2017.

Rita, Kencana. Pengembangan Nilai Moral dan Agama Anak Usia Dini. Bandung: Edu Publiser, 2020. 
Rivai, Veithzal. Kepemimpinan dan Perilaku Organisasi. Jakarta: Rajawali Press, 2009.

Rohmah, C. O. Pengaruh Penggunaan Gadget dan Lingkungan Belajar terhadap Minat Belajar Siswa Kelas XI Kompetensi Keahlian Administrasi Perkantoran SMK Muhammadiyah 2 Yogyakarta. Skripsi. Fakultas Ekonomi UNY, 2017.

Saleh, Muwafik. Membangun Karakter dengan Hati Nurani. Jakarta: Erlangga, 2012.

Sjarkawi. Pembentukan Kepribadian Anak: Peran Moral Intelektual, Emosional dan Sosial sebagai Wujud Membangun Jati Diri. Jakarta: PT Bumi Aksara, 2009.

Soetjiningsi, Christiana Hari. Seri Psikologi Perkembangan Anak. Jakarta: Kencana, 2018.

Subagijo Azimah. Diet dan Detoks Gadget. Jakarta: PT Mizan Publika, 2020.

Susanti, Atik Dwi. Pengaruh Pemanfaatan Gadget dalam Aktivitas Belajar untuk Meningkatkan Hasil Belajar Ppkn Siswa di Kelas Xi Iis Sma Negeri 1 Seputih Mataram. Skripsi. FKIP Universitas Lampung Bandar Lampung, 2018.

Suwarsi. "Pengaruh Gadget terhadap

Perkembangan Anak". Seminar 25 September 2016.

Sylvie, Puspita. Fenomena Kecanduan Gadget Pada anak Usia Dini. Surabaya: Cipta Media Nusantara, 2020.

Wahyu, Novitasari. Dampak Penggunaan Gadget tehadap Interaksi Sosial Anak. Disertasi. Surabaya: Universitas Negri Surabaya, 2016), 22.

Wijanarko, Jarot \& Ester Setiawati, Ayah Baik-Ibu Baik Parenting Era Digital. Jakarta: Keluarga Indonesia Bahagia, 2016.

Yahya, Yudrik. Psikologi Perkembangan. Jakarta: PT Kharisma Putra Utama, 2000. 